\title{
Statyba
}

\section{ANALYSIS OF PARAMETERS AFFECTING TENSION STIFFENING IN REINFORCED CONCRETE BEAMS}

\section{G. Kaklauskas PhD \& R. Šimkus}

To cite this article: G. Kaklauskas PhD \& R. Šimkus (1998) ANALYSIS OF PARAMETERS AFFECTING TENSION STIFFENING IN REINFORCED CONCRETE BEAMS, Statyba, 4:4, 260-265, DOI: $10.1080 / 13921525.1998 .10531415$

To link to this article: https://doi.org/10.1080/13921525.1998.10531415

曲 Published online: 26 Jul 2012.

Submit your article to this journal

山 Article views: 68 


\title{
ANALYSIS OF PARAMETERS AFFECTING TENSION STIFFENING IN REINFORCED CONCRETE BEAMS
}

\author{
G. Kaklauskas, R. Šimkus
}

\section{Introduction}

The author with co-authors proposed a method [1-6] for determining the average tensile and compressive stress-strain relationships for concrete in reinforced concrete beams. The concrete stress-strain relationships are determined directly from the momentcurvature (average strain) diagrams obtained from flexural experiments on reinforced concrete beams. The proposed incremental method casts the determination of the stress-strain relationship in the form of an initial condition problem, and at each stage of loading uses the previously determined portions of the stress-strain curves.

In [7] the proposed methodology has been applied to a number of accurately performed flexural experiments on reinforced concrete beams reported by Clark and Speirs [8]. Fourteen beams with various depths, reinforcement ratios and diameter (Table 1) were tested under a four-point loading system which gave a constant moment zone of $1.2 \mathrm{~m}$ and two shear spans of $1.0 \mathrm{~m}$. Each beam was reinforced with three bars of tensile reinforcement and two bars of compressive reinforcement. Two series of beams have been investigated: in the first series (beam nos 1 through 4), the overall depth was held constant, but

Table 1. Nominal geometrical data of specimens

\begin{tabular}{|c|c|c|c|c|}
\hline Specimen & $\begin{array}{c}\text { Width } \\
(\mathrm{mm})\end{array}$ & $\begin{array}{c}\text { Depth } \\
(\mathrm{mm})\end{array}$ & $\begin{array}{c}\text { Reinfor- } \\
\text { cement } \\
\text { ratio } \\
(\%)\end{array}$ & $\begin{array}{c}\text { Reinfor- } \\
\text { cement } \\
\text { diamete } \\
\mathrm{r}(\mathrm{mm})\end{array}$ \\
\hline 1 and 1R & 200 & 400 & 1.95 & 25 \\
2 and 2R & 200 & 400 & 1.27 & 20 \\
3 and 3R & 200 & 400 & 0.79 & 16 \\
4 and 4R & 200 & 400 & 0.45 & 12 \\
5 and 5R & 200 & 200 & 1.78 & 16 \\
6 and 6R & 200 & 300 & 1.10 & 16 \\
7 and 7R & 200 & 500 & 0.63 & 16 \\
\hline
\end{tabular}

reinforcement diameter and therefore area was varied. In the second series (nos 3,5,6 and 7), the steel area was kept constant, but the overall depth was varied. In Table 1, the letter ' $R$ ' after the specimen number indicates that a second nominally identical beam was tested. The tests were terminated prior to, or at the onset of, the yielding of the reinforcement. Experimental results in [8] are presented in terms of moment-curvature $(M-\kappa)$ and moment-steel strain $\left(M-\varepsilon_{s}\right)$ diagrams for each of the specimen.

Average stress-strain relationships for concrete in tension have been determined for all the beams. The $\sigma_{t}-\varepsilon_{t}$ relations obtained from $M-\kappa$ diagrams for beams of the first and second series are shown in Figs 1 and 2 respectively. Such parameters as reinforcement ratio and rebar diameter, section depth and shrinkage affecting the shape of the stress-strain curves (or tension stiffening effect) are discussed in this paper.

\section{Analysis of the stress-strain relations in tension}

The beams assigned to the first series had constant thickness, width, and constant number of reinforcement bars, but varying diameter and, therefore, area of reinforcement. Two striking features of the curves shown in Fig 1 are discussed below.

1) Tension stiffening effect is considerably more pronounced for beams $3(\mathrm{R})$ and $4(\mathrm{R})$ having smaller reinforcement ratio and diameter than beams $1(R)$ and $2(\mathrm{R})$ with larger reinforcement ratio and diameter (Table 1). Higher maximum stresses are reached for beams with smaller reinforcement ratio. Maximum stresses for beams $1(R)$ and $2(R)$ are far less than the experimental tensile strength which was over $2 \mathrm{MPa}$ for all the beams. This indirectly implies that significant tensile concrete stresses caused by shrinkage were present prior to the test. Beams with smaller reinforcement ratio and diameter reached much greater tensile concrete strains with corresponding positive 
stresses. Unfortunately, it is difficult to separate the influence of two parameters - reinforcement ratio and diameter on tension stiffening since each of the beams had three reinforcement bars in the tensile zone. Besides, influence of reinforcement ratio is coupled with shrinkage effects, especially for members with higher reinforcement ratio.

One might speculate that tension stiffening is the tensile concrete property due to bond with reinforcement. The larger the reinforcement surface area, the better the bond, and consequently, more pronounced tension stiffening effect. Then the reinforcement diameter would have the crucial importance. This was confirmed by experimental investigation of large reinforced concrete members subjected to tension [9]. It

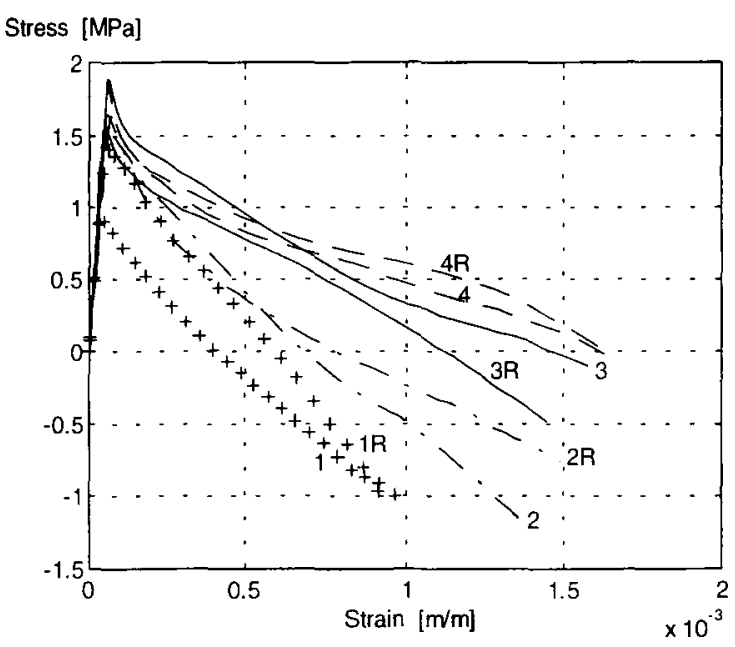

Fig 1. Tensile concrete stress-strain relationships for the beams of the first series having constant section height but varying reinforcement area and diameter

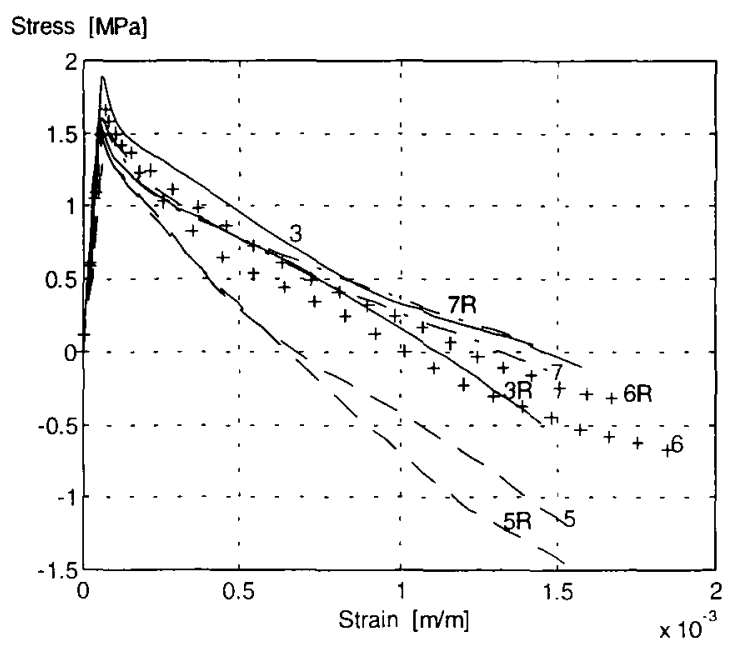

Fig 2. Tensile concrete stress-strain curves for the beams of the second series having constant reinforcement area and diameter but varying section height was shown that for the constant reinforcement ratio, decrease in diameter (increase in a number of reinforcement bars and, therefore, in surface area) leads to significant increase in tension stiffening.

2) Computed $\sigma_{t}-\varepsilon_{t}$ curves for the specimens with higher reinforcement ratio have a significant portion of negative stresses. If the possibility of momentstrain measurement errors is excluded, this can be explained by this: a) due to shrinkage, significant tensile concrete stresses and negative stresses in tensile reinforcement were present prior to the test; b) assumption of the constant $\sigma_{t}-\varepsilon_{t}$ diagram for all tensile concrete fibres is inaccurate. As it was described earlier, the $\sigma_{t}-\varepsilon_{t}$ diagram is computed for the extreme fibre assuming that other fibres follow the same law. At the initial cracking stages, the computed $\sigma_{t}-\varepsilon_{t}$ curve actually represents average stresses of the fibres close to the extreme surface and reinforcement. Say, these fibres at a certain average strain $\widetilde{\varepsilon}_{t}>\varepsilon_{c r}$ carry some average stress $\widetilde{\sigma}_{t}$. When a tensile fibre distant from the reinforcement at a certain load stage reaches the same strain $\widetilde{\varepsilon}_{t}$, it is assumed that it carries the same average stress $\widetilde{\sigma}_{t}$. However, this is not true, because distant fibres are less affected by bond with reinforcement and, therefore, carry lesser stresses. When equilibrium equations are solved, in order to compensate for these increased stresses, stresses in the extreme fibre are reduced; c) assumption of perfect bond between tensile reinforcement and concrete is not accurate. Reinforcement slippage may occur at advanced stress-strain states, particularly for beams reinforced with bars of larger diameters. Such beams have relatively small reinforcement perimeter and respective bond surface leading to larger bond stresses.

As it was indicated in [7], for members with higher reinforcement ratios, $\sigma_{t}-\varepsilon_{t}$ curve has little effect on the curvature and deflection calculation. Therefore, the negative stress portions of $\sigma_{t}-\varepsilon_{t}$ diagrams can be simply excluded. Besides, the negative stress parts can be reduced or even eliminated if shrinkage effects are assessed.

Computed $\sigma_{t}-\varepsilon_{t}$ diagrams from $M-\kappa$ diagrams for the beams $3(\mathrm{R}), 5(\mathrm{R}), 6(\mathrm{R})$ and $7(\mathrm{R})$ of the series 2 are shown in Fig 2. The beams had constant tensile reinforcement area and diameter ( 3 bars 16 $\mathrm{mm}$ in diameter), but increasing depth in the order $7>3>6>5$. Since the reinforcement diameter in this case was constant, tension stiffening was influenced by 
two parameters: reinforcement ratio and section depth. Again one might speculate that tension stiffening should be higher in members with lesser section depth since the tensile concrete fibres are closer to reinforcement than those sections with greater depths. On the other hand, the specimens with lower depth had higher reinforcement ratio leading to decrease in tension stiffening. As it can be seen from Fig 2, beams 5 and $5 \mathrm{R}$ with the highest reinforcement ratio and the smallest depth (Table 1) have the least expressed tension stiffening effect. Stress-strain relations for the remaining beams are very similar, but some increase in tension stiffening can be noted for beams with decreasing reinforcement ratio. This indirectly implies that the two parameters - reinforcement ratio and section depth have the opposite effect on tension stiffening although the first factor has larger quantitative effect. It should be noted again that higher reinforcement ratio is accompanied with higher shrinkage stresses which reduce tension stiffening. Besides, shrinkage is increased in the members with smaller cross-section area, ie lesser depth.

In order to check the accuracy of the $\sigma_{t}-\varepsilon_{t}$ curves computed for the beams (Figs 1 and 2), those curves were used to compute moment-curvature diagrams which were then compared with the initially assumed diagrams. Results for beams 1 through 4 are presented in Fig 3. Excellent agreement has been achieved between the initially assumed $M-\kappa$ diagrams represented by the solid lines and the relations obtained using the full $\sigma_{t}-\varepsilon_{t}$ curves and represented by open circles. When the negative portions of the $\sigma_{t}-\varepsilon_{t}$ curves are excluded, the computed $M-\kappa$ relations as represented by crosses deviated slightly from the other two relations for beams 1 and 2, but not for beams 3 and 4 .

\section{Analysis of shrinkage effects}

Non-linear effects of creep and shrinkage along with cracking provide the major concern to the structural designer because of the inaccuracies and unknowns that surround them. Although creep and shrinkage are considered as long-term factors, even short-term stress-strain analysis would be far less accurate without inclusion of these effects. Shrinkage occurs more pronounced during the first few months than does creep. Typically, about $90 \%$ of shrinkage and creep will have occurred at the end of one and five years respectively.
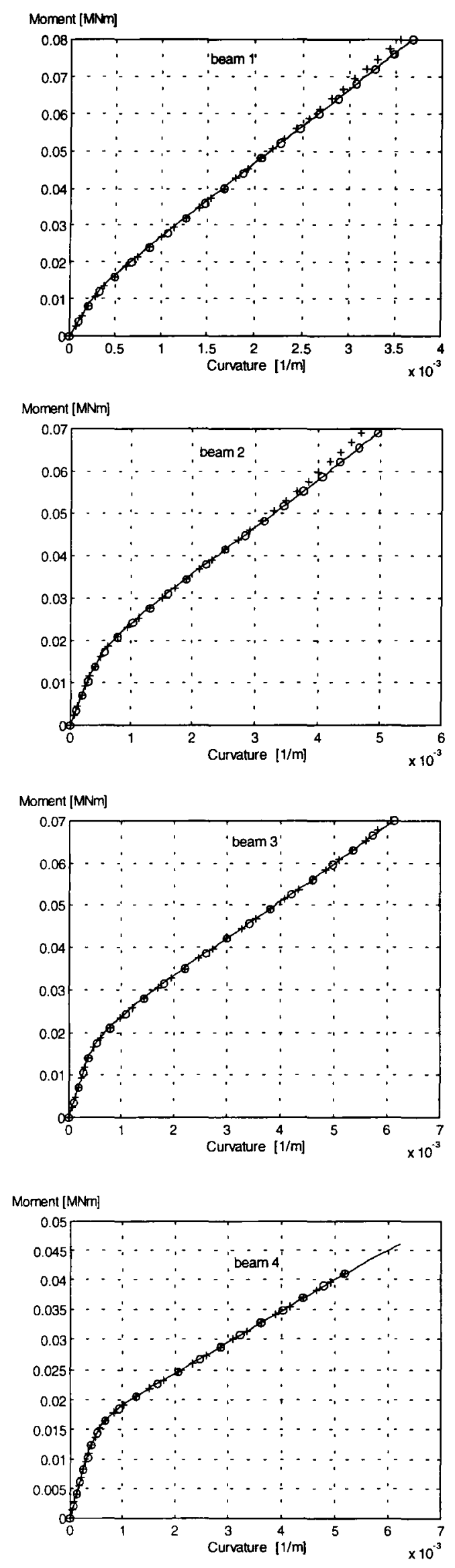

Fig 3. Comparison of experimental and computed $M-\kappa$ curves for beams 1 to 4 
Shrinkage of an isolated plain concrete member would merely shorten it without causing curvature. Reinforcement embedded in a concrete member provides restraint to shrinkage leading to compressive stresses in reinforcement and tensile stresses in concrete. If the reinforcement is not symmetrically placed on a section, shrinkage causes warping. Even at the initial stages of warping when the structure may not be subjected to gravity or live loading, creep effects take place causing curvature increase with time. Since concrete is an aging material, its strength and modulus of elasticity increase with time as well as does shrinkage strain. Analysis is also complicated by interdependence between stress history and creep strain. TrostBazant method, sometimes called the age adjusted modulus method $[10,11]$ gives a simple procedure for computing a strain under a varying stress. The method introduces the aging coefficient $\chi(t, \tau)$ which assesses that stress $\sigma_{0}$ applied instantly at time $\tau_{0}$ and kept constant until time $t$ will cause greater strain than gradually from time $\tau_{0}$ to $t$ applied stress $\Delta \sigma(t)=\sigma_{0}$ greater strain than gradually from time $\tau_{0}$ to $t$ applied stress $\Delta \sigma(t)=\sigma_{0}$.

In a common case when initial stress $\sigma_{0}$ applied at time $\tau_{0}$ is gradually increasing (decreasing) with a total increment $\Delta \sigma(t)$ at time $t$, the total strain can be expressed as follows:

$$
\begin{aligned}
& \varepsilon(t)=\frac{\sigma_{0}}{E_{c}\left(\tau_{0}\right)}\left[1+\Phi\left(t, \tau_{0}\right)\right]+ \\
& +\frac{\Delta \sigma(t)}{E_{c}\left(\tau_{0}\right)}\left[1+\chi\left(t, \tau_{0}\right) \Phi\left(t, \tau_{0}\right)\right]+\varepsilon_{s h}(t)
\end{aligned}
$$

where $\Phi\left(t, \tau_{0}\right)$ is the creep coefficient; $\varepsilon_{s h}(t)$ is a mean free shrinkage of concrete; $E_{c}\left(\tau_{0}\right)$ is modulus of elasticity of concrete at time $\tau_{0}$.

For shrinkage investigation problems when $\sigma_{0}=0, \mathrm{Eq}(1)$ becomes:

$$
\varepsilon(t)=\frac{\Delta \sigma(t)}{E_{c}\left(\tau_{0}\right)}\left[1+\chi\left(t, \tau_{0}\right) \Phi\left(t, \tau_{0}\right)\right]+\varepsilon_{s h}(t)
$$

It must be noted that factors $\varepsilon_{s h}(t), \Phi\left(t, \tau_{0}\right)$ and $\chi(t, \tau)$ of $\mathrm{Eq}(2)$ are most uncertain for early shrinkage problems and their estimates obtained from different methods vary widely.

Free shrinkage strain $\varepsilon_{s h}(t)$ is the most important parameter in shrinkage investigation. Since shrinkage is primarily related to moisture loss, it is mostly affected by humidity. For relative humidity
$\mathrm{H}=50 \%$, free concrete shrinkage strain is about $50 \%$ greater than for $\mathrm{H}=80 \%$. Other factors influencing shrinkage are initial curing conditions, geometry of cross-section, water-cement ratio, cement content, percent of fine aggregates, air content, etc. Prediction of shrinkage strain $\varepsilon_{s h}(t)$ obtained from different methods [10-17] vary woefully giving a difference over 2.5 times for extreme estimates.

Creep is mainly affected by similar factors as shrinkage. Among some extra factors, age at loading of structure is considered as one of the most important. Although estimates of creep coefficient $\Phi\left(t, \tau_{0}\right)$ by different methods [10-17] also vary widely, in the present context it is not very significant since $\Phi\left(t, \tau_{0}\right)$ acquires relatively small values for early ages of concrete.

Determination of aging coefficient $\chi(t, \tau)$ is also uncertain for early age concrete. Aging coefficient $\chi(t, \tau)$ proposed by different authors $[18,19,20,21]$ vary from 0.5 to 0.98 for load duration less than 100 days. However, this is not again very significant, because the aging coefficient is associated with small creep coefficient so that the product of two factors does not significantly affect the total value of $\mathrm{Eq}$ (2).

Time-dependent stresses in a reinforced concrete member are derived on a basis of equilibrium and compatibility of strains under condition of perfect bond. For $\mathbf{n}$ layers of steel, a set of $\mathbf{n}$ equations with $\mathbf{n}$ unknowns has to be solved. An example of such derivation for uncracked doubly reinforced concrete member is given in [22].

An attempt was made to assess shrinkage caused stresses for the experimental specimens [8]. From the several methods considered, ACI method [10] has been chosen for prediction of free shrinkage strain and creep coefficient. The age of specimens at test is indicated in [8], but important information on curing conditions is missing. Since the tests were carried out in the laboratory conditions, the humidity assumed was $\mathrm{H}=50 \%$ what corresponds to average indoor exposure. It was also assumed that the specimens were moist cured for 7 days. The analysis included assessment of actual age and cross-section of specimens.

Analysis have shown that neither of the specimens had cracked prior to the test. Strains (and stresses) in reinforcement due to shrinkage computed for different specimens varied far less significantly than internal forces in reinforcement. Strains in the top reinforcement were $90-100 \%$ and in the bottom 
reinforcement $50-85 \%$ of the free shrinkage strain where smaller numbers correspond to higher reinforcement ratios and larger numbers to smaller reinforcement ratios. Due to different reinforcement area, total forces in reinforcement were ranging from $20.0 \mathrm{kN}$ (small reinforcement ratios) to $50.0 \mathrm{kN}$ (high reinforcement ratios). Due to the different forces in reinforcement, stresses in tensile concrete varied significantly, though stresses in the extreme compressive fiber for most of specimens were close to zero. Tensile concrete stresses in the extreme fiber varied from 0.5 $\mathrm{MPa}$ in beam 4 to $1.3 \mathrm{MPa}$ in beam 1 . This may serve as an explanation why maximum tensile stresses in the computed $\sigma_{t}-\varepsilon_{t}$ curves (Figs 1 and 2) were lower for specimens with higher reinforcement ratios. Actually, a sum of the maximum tensile concrete stress due to shrinkage and the maximum stress in $\sigma_{t}-\varepsilon_{t}$ diagram should give a tensile concrete strength in bending.

Stresses in the bottom reinforcement due to shrinkage drop significantly after cracking and almost disappear with yielding of reinforcement. Time dependent analysis of cracked members assuming full material $\sigma_{t}-\varepsilon_{t}$ diagram is more complicated and makes no sense when experimental data contain no information regarding shrinkage.

\section{Conclusions}

An analysis of average stress-strain relations for concrete in tension defined from flexural tests of reinforced concrete beams has been carried out. Fourteen beams with various depths, reinforcement ratios and diameter have been investigated. The analysis has shown that tension stiffening effect is more pronounced for beams with smaller reinforcement ratio and diameter than beams having larger reinforcement ratio and diameter. Beams with smaller reinforcement ratio and diameter reached much greater tensile concrete strains with corresponding positive stresses. Unfortunately, it is difficult to separate the influence of the two parameters - reinforcement ratio and diameter on tension stiffening since each of the beams had three reinforcement bars in the tensile zone. Besides, the influence of reinforcement ratio was coupled with shrinkage effects, especially for members with higher reinforcement ratio. It has been indirectly found out that decrease in a free concrete shrinkage strain as well as in section depth favourably affects tension stiffening.

\section{Acknowledgments}

Part of this work was carried out by the first author in the Department of Civil Engineering of the University of Illinois, Urbana-Champaign, USA. Professors J.Ghaboussi and N.Hawkins are gratefully thanked for their critical support and advice throughout the research. The financial support provided by the University of Illinois and US Information Agency under Fulbright grant is gratefully acknowledged.

\section{References}

1. G. Kaklauskas. A Method for Determination of StressStrain Relations for Concrete from Experimental Data of RC Bending Members // Statyba, No 2(10). Vilnius: Technika, 1997, p. 60-68.

2. G. Kaklauskas. Practical Techniques for Determining Average Stress-Strain Relationships for Concrete from Experimental Data of RC Bending Members // Statyba, Vol IV, No 1. Vilnius: Technika, 1998, p. 20-28.

3. G. Kaklauskas. A Method for Investigation of Tension Stiffening Effect of Flexural RC Members // Proceedings, Conf. Building and Architecture, Kaunas, Lithuania, April 9-11, 1997, p. 157-164.

4. G. Kaklauskas, J. Ghaboussi and N. M. Hawkins. Determination of Stress-Strain Curves for Concrete from RC Beam Tests // Proceedings, Fifth Int. Conf. Modern Building Materials and Techniques. Vilnius, Lithuania, May 21-24, 1997. V.: Technika, 1997, Vol I, p. 138-145.

5. G. Kaklauskas. A Technique for Investigation of Tension Stiffening Effect of Flexural RC Members // Proceedings, 10th Nordic Seminar on Computational Mechanics. Tallinn, Estonia, October 24-25, 1997, p. 228231.

6. G. Kaklauskas, J. Ghaboussi, and X.Wu. Neural Network Modelling of Tension Stiffening Effect for R/C Flexural Members // Proceedings, EURO-C 1998- Computational Modelling of Concrete Structures. Badgastein, Austria, March 31 - April 3, 1998 ( to be published).

7. G. Kaklauskas. Average Stress-Strain Relations for Concrete from Experimental Moment-Strain Diagrams of Beams and Slabs // Statyba, Vol IV, No 2. Vilnius: Technika, 1998, p. 92-101.

8. L. A. Clark and D. M. Speirs. Tension Stiffening in Reinforced Concrete Beams and Slabs under Short-Term Load // Technical Report No. 42.521, Cement and Concrete Association, London, 1978.20 p.

9. A. Williams. Tests on Large Reinforced Concrete Elements Subjected to Direct Tension // Technical Report No. 42.562, Cement and Concrete Association, London, 1986. $56 \mathrm{p}$.

10. ACI Committee 209. Prediction of Creep, Shrinkage and Temperature Effects in Concrete Structures // ACI Manual of Concrete Practice. Part I. American Concrete Institute (ACI), Detroit, Mich., 1990.

11. Comite Euro-International Du Beton. Bulletin D'Information N.124/125-E-CEB-FIP // CEB-FIP Model Code 
for Concrete Structures, English Translation, April 1978

12. Comite Euro-International Du Beton // CEB-FIP International Recommendations for the Design and Construction of Concrete Structures, Paris-London.

13. Standards Association of Australia // SAA Prestressed Concrete Code - AS 1481-1978, Sydney, 1978.

14. Z. P. Bazant and L. P. Panula. Practical Predictions of Time Dependent Deformations of Concrete // Materials and Structures, 11, No. 65, 1978, No. 66, 1978, 12, No 69, 1979.

15. British Standards Institution. British Standard, Structural Use of Concrete, Part 2, Code of Practice for Special Circumstances, BS 8110: Part2: 1985.

16. H. K. Hilsdorf and H.S. Müller. Comparison of Methods to Predict Time-Dependent Strains of Concrete // Institut für Baustofftechnologie, Universität Karlsruhe (TH), 1979. $91 \mathrm{p}$.

17. R. I. Gilbert. Time Effects in Concrete Structures. Elsevier, Amsterdam, 1988.

18. H. Trost. Auswirkungen des Superpositionsprinzips auf Kriech- und Relaxation-probleme bei Beton und Spannbeton // Beton. Stahlbeton., 62, No 10, 1967, p. $230-238$

19. Z. P. Bazant. Prediction of Concrete Creep Effects Using Age-Adjusted Effective Modulus Method, J. Am. C. Inst. 69 , No 4, 1972, p. 212-217.

20. D. Schade. Alterungsbeiwerte für das Kreichen von Beton nach den Spannbetonrichtlinien // Beton. Stahlbeton., 5, 1977, p. 113-117.

21. W. H. Dilger. Methods of Structural Creep Analysis // Creep and Shrinkage in Concrete Structures. John Willey and Sons, 1982, p. 305-339.

22. A. M. Neville and W. H. Dilger. Creep of Plain and Structural Concrete. London: Longman, 1982.

İteikta 19980403

\section{FAKTORIU, VEIKIANČIỤ SUPLEIŠĖEJUSIO TEMPIAMO BETONO DARBĄ GELŽBETONINĖSE SUOSE, ANALIZi}

\section{G. Kaklauskas, R.Šimkus}

\section{Santrauka}

Ankstesniame straipsnyje [7] buvo rašyta, kad taikant pirmojo autoriaus sukurtą metodą [1-6] keturiolikai eksperimentiniu gelžbetoniniu siju [8] buvo nustatytos tempiamo betono vidutiniu ịtempiu-deformaciju kreives. Sijos turejo skirtingą skerspjūvio aukštị, armavimo koeficientą ir armatūros strypų skersmeni (1 lent.). Jos buvo suskirstytos i dvi grupes (serijas): pirmosios serijos (No 1-4) sijos turejo skirtingą aukštị, skirtingą armatūros strypu skersmenị ir skerspjūvio plotą. Antrojoje serijoje (No 3, 5, 6 ir 7) armatūros strypų skerspjūvio plotas ir skersmuo buvo vienodi, tačiau kito siju skerspjūvio aukštis. Raide $R$ bandinio numeryje (1 lent.) rodo, jog buvo išbandyta identiška sija. Tempiamo betono vidutiniu įtempiu-deformaciju diagramos pirmosios ir antrosios seriju sijoms pateiktos atitinkamai 1 ir 2 pav. Šiame straipsnyje analizuojamos gautosios diagramos vertinant svarbiausių faktoriu įtaką.
Svarbiausias itempiu-deformaciju kreiviu, gautu pirmosios serijos sijoms, bruožas yra tas, kad siju 3(R) ir 4(R), turinčiu mažą armavimo koeficientą ir strypu skersmenị, kreivès turi žymiai ilgesnę krintančią teigiamy ịtempių dali nei sijų $1(R)$ ir 2(R) kreivès. Tai galima paaiškinti tuo, kad, mažinant strypu skersmeni, santykiškai (paliekant ta pati skerspjūvio plotą) padideja ju paviršiaus plotas, o kartu pagereja armatūros tempiamo betono sukibimas. Tai ir sąlygoja efektyvesnị tempiamo betono tarp plyšił darbą. Reikia paminèti, kad šiuo atveju sunku atskirai vertinti minimu faktoriu (armavimo koeficiento ir strypu skersmens) ittaką, nes visos sijos turejo po tris tempiamos armatūros strypus, t.y., didejant strypu skersmeniui, didejjo ir skerspjūvio plotas. $\mathrm{Be}$ to, reiškini komplikuoja betono susitraukimą sukeliančios deformacijos, kurios dideja, didejant armavimo koeficientui.

Kitas ryškus ịtempių-deformacijų kreivių bruožas yra tas, kad kai kurioms sijoms (ypač turinčioms didesni armavimo koeficienta) nustatytos kreives turi neigiamus itempius. Tai gali atsitikti dèl trijų priežasčiu, kurios nurodomos straipsnyje. Apskaičiavimais buvo parodyta, kad, atmetus neigiamą ittempių-deformaciju kreivès dalị, apskaičiuota momentų-kreivių diagrama nežymiai skiriasi nuo eksperimentines diagramos (3 pav.).

Lyginant ittempių-deformaciju kreives, gautas antrosios serijos sijoms (2 pav.), galima padaryti išvadą, kad tempiamo betono darbas tarp plyšių tampa efektyvesnis, mažejant ne tik armavimo koeficientui, bet ir skerspjūvio aukščiui. Pastarojo faktoriaus ittaką galima paaiškinti tuo, kad mažesnio skerspjūvio siju tempiamo betono sluoksniai vidutiniškai yra arčiau armatūros nei didelio skerspjūvio, todèl, esant toms pačioms deformacijoms, jie turi didesnius ittempius.

Straipsnyje aptariama betono susitraukimo ittaka konstrukcijy itempiams ir deformacijoms.

Gintaris KAKLAUSKAS. PhD, Senior Researcher and Associate Professor. Dept of Reinforced Concrete Structures, Vilnius Gediminas Technical University, Sauletekio al. 11, 2040 Vilnius, Lithuania.

A graduate of Vilnius Civil Engineering Institute (presently Vilnius Gediminas Technical University, VGTU), 1982 (civil engineer). PhD degree, 1990. Research visits: Aalborg University (Denmark), 1991, University of Glamorgan (UK), 1994/1995, University of Illinois, UrbanaChampaign (USA), 1996. Author and co-author of 2 monographs, 1 invention and a number of papers. Research interests: development of average stress-strain relationships for concrete in tension and numerical simulation of reinforced concrete flexural structures.

Regimantas SIMKUS. Researcher. Institute of Building and Architecture. Tunelio 60, 3000 Kaunas, Lithuania.

A graduate of Kaunas Politechnical Institute (presently Kaunas Technological University, KTU), 1973 (civil engineer). After graduation with some interruptions works at research Institute of Building and Architecture in Kaunas. Author and co-author of a number of papers. Research interests: development of analytical and statistical methods for deflection calculation of reinforced concrete flexural structures. 